\title{
PENGARUH PEMBELAJARAN MIKRO TERHADAP KESIAPAN PROGRAM MAGANG III MAHASISWA PRODI PENDIDIKAN GEOGRAFI
}

\author{
${ }^{1)}$ Yuli Ifana Sari, ${ }^{2)}$ Nila Restu Wardani \\ ${ }^{1)}{ }^{2)}$ Universitas Kanjuruhan Malang \\ E-mail: ${ }^{1)}$ ifana@unikama.ac.id; ${ }^{2)}$ nilarestu@unikama.ac.id
}

\begin{abstract}
Abstrak
Kematangan calon guru menjadi tolak ukur yang digunakan untuk mewujudkan guru yang berkompetensi di bidangnya. Tujuan penelitian ini adalah untuk menganalisis dan mengetahui: pengaruh yang signifikan antara pembelajaran mikro terhadap kesiapan program magang III. Populasi adalah mahasiswa Pogram Studi Pendidikan Geografi semester VIII yang telah menempuh matakuliah pembelajaran mikro dan magang III sejumlah 156 mahasiswa. Teknik sampling dalam penelitian ini adalah Proportional random sampling. Instrumen penelitian yang digunakan yakni penilaian kemampuan merencanakan pembelajaran dan kemampuan melaksanakan pembelajaran. Pengujian hipotesis dalam penelitian ini menggunakan t-test.
\end{abstract}

Kata Kunci: Pembelajaran mikro, kesiapan program magang III

\section{PENDAHULUAN}

Menghadapi jaman yang semakin global, dalam dunia pendidikan terutama Lembaga Pendidikan Tenaga Kependidikan dituntut selalu aktif dalam meningkatkan kompetensi lulusannya agar dapat bersaing di dunia global dan sesuai dengan perkembangan jaman. Pembaharuan di bidang pendidikan haruslah dilakukan secara terus-menerus agar dapat memenuhi kebutuhan masyarakat. Dalam hal ini Prodi Pendidikan Geografi Universitas Kanjuruhan Malang memiliki tujuan dalam hal peningkatan produktivitas tenaga kependidikan agar calon pendidik dapat memenuhi kompetensi pendidikan yang berkarakter dan profesional serta memberi arahan pada perubahan pendidikan yang lebih baik. Slameto (2010:115) mendiskripsikan kematangan sebagai "proses yang menimbulkan perubahan tingkah laku sebagai akibat dari pertumbuhan dan perkembangan". Kematangan calon guru menjadi tolak ukur yang digunakan untuk mewujudkan guru yang berkompetensi di bidangnya.

Struktur dan isi kurikulum Prodi Pendidikan Geografi berorientasi pada pembekalan dan pengembangan standar kompetensi lulusan yang memenuhi kriteria standar kompetensi guru mata pelajaran geografi. Standar kompetensi guru meliputi empat komponen, yakni: kompetensi pedagogik, kompetensi kepribadian, kompetensi profesional, dan kompetensi sosial. Proses pembentukan profesionalisme dan kompetensi guru pada mahasiswa calon guru geografi ditumbuhkembangkan melalui perkuliahan. Matakuliah Belajar dan Pembelajaran Geografi termasuk ke dalam rumpun matakuliah keahlian belajar (MKKB). Mata kuliah tersebut bertujuan untuk mengembangkan dan membekali mahasiswa calon guru mata pelajaran geografi dengan kompetensi pedagogik dan kompetensi profesional. Untuk mencapai tujuan tersebut, maka mahasiswa difasilitasi untuk 
mendapatkan pengetahuan dan keterampilan dasar mengajar.

Usaha lain yang ditempuh dalam meningkatkan kompetensi dalam mencapai mutu bidang kependidikan antara lain ialah adanya program magang III yang berbobot 3 SKS. Program tersebut menjadi salah satu langkah dalam mendekatkan kesesuaian antara kualitas lulusan dengan permintaan tenaga kerja, khususnya sebagai calon tenaga guru. Usaha ini di sesuaikan dengan tuntutan jaman yang selalu menghendaki adanya perubahan dalam segala bidang terutama bidang pendidikan, yang dirasa masih perlu adanya peningkatan kualitas sumber daya manusia yaitu tenaga pengajar yang berkualitas profesional dan proses belajar mengajar yang selaras dengan kurikulum yang telah ditentukan oleh Prodi Pendidikan Geografi Universitas Kanjuruhan Malang. Usaha keefektifan program magang III berlandaskan hasil penelitian Cahyati (2014) yang menyimpulkan "Praktik Pengalaman Lapangan (PPL) berpengaruh positif terhadap tingkat kematangan calon guru pada mahasiswa FKIP Akuntansi angkatan tahun 2010 Universitas Muhammadiyah Surakarta”.

Pembelajaran mikro dalam konteks pelaksanaan program magang III, tidak berarti bahwa pembelajaran mikro sebagai pengganti praktik mengajar, melainkan berfungsi sebagai alat pembantu/pelengkap. Dengan kata lain, latihan praktik mengajar tidak berhenti sampai dikuasainya komponenkomponen keterampilan mengajar di dalam pembelajaran mikro, tetapi perlu diteruskan sehingga calon guru dapat menerapkan kemampuan mengajarnya secara komprehensif dalam real classroom teaching. Dengan demikian dapat terbinalah performance seorang guru yang diperlukan di depan kelas.

Pendapat tersebut berdasarkan hasil penelitian dari Mukondar dan Susanto (2015) yang menyimpulkan bahwa "matakuliahh Pembelajaran Mikro dapat mempengaruhi kesiapan Praktik Pengalaman Lapangan (PPL) mahasiswa program studi pendidikan teknik otomotif Universitas Muhammadiyah Purworejo". Pembelajaran micro teaching merupakan pelatihan tahap awal dalam membentuk kompetensi dan keterampilan mengajar melalui pengaktualisasian kompetensi dasar mengajar.

Micro teaching (pembelajaran mikro) merupakan salah satu cara latihan bagi mahasiswa calon guru untuk praktik mengajar dilakukan dalam proses belajar mengajar yang dimakrokan untuk membentuk atau mengembangkan keterampilan mengajar. Situasi belajar mengajar itu sengaja didesain sedemikian rupa sehingga dapat dikontrol, maka pembentukan keterampilan baru ataupun pembaharuan suatu keterampilan mengajar dalam situasi laboratoris bisa berjalan lancar dan pengajaran dalam keadaan terkontrol untuk meningkatkan kompetensinya. Akan tetapi perlu dilihat faktor lain yang dapat menghambat belajar mahasiswa dalam pembelajaran mikro yaitu "mahasiswa merasa bingung untuk mencari materi yang akan disusun kemudian memilih dan menemukan silabus apa yang akan dipakai" (Andrasmoro dan Nurekawati, 2016). Hal itu disebabkan semangat belajar dan berusaha mencari informasi mahasiswa cenderung melemah, oleh sebab itu dilakukan bimbingan dan pemberian 
motivasi oleh dosen pengampu matakuliahh pembelajaran mikro.

Universitas Kanjuruhan Malang sebagai Lembaga Pendidikan Tenaga Kependidikan (LPTK) telah merancang dan menetapkan program magang sebagai bagian integral kurikulum yang dilaksanakan secara berjenjang, yaitu magang I, magang II, dan magang III. Setiap program magang dilaksanakan dengan waktu dan tujuan yang berbeda.

Masing-masing program magang
memiliki bobot SKS sebagai berikut
magang I berbobot 1 SKS, magang II
berbobot 1 SKS, dan magang III
berbobot 3 SKS. Kegiatan magang
tersebut dilaksanakan pada komunitas
sekolah, sedangkan pembimbingannya
dilakukan oleh Dosen Pembimbing
Magang (DPM) dan Guru
Pembimbing Magang (GPM) di
sekolah yang memenuhi persyaratan
sebagaimana yang ditentukan (LP3L,
2016).

Magang merupakan pembelajaran dengan berbuat, sangat tepat untuk memenuhi kebutuhan mahasiswa sebagai calon pendidik. Melalui magang pengetahuan dan sikap terbentuk melalui pengalaman dalam menyelesaikan kegiatan-kegiatan yang ditugaskan termasuk mengatasi masalah-masalah yang dihadapi di lapangan.

Kesiapan mahasiswa Prodi Pendidikan Geografi terhadap pelaksanaan Program Magang III telah diatur dalam rangkaian perkuliahan mahasiswa selama enam semester sebelumnya. Langkah-langkah yang telah ditempuh Prodi Pendidikan Geografi antara lain menanamkan perilaku baik terhadap mahasiswa yang nantinya menjadi calon guru selama masa perkuliahan, aspek kerapian dan penampilan diri, kedisiplinan, tertib administrasiperkuliahan, berkepribadian baik, mampu berfikir, dan bertindak secara bertanggungjawab. Langkah- langkah tersebut adalah upaya dalam pembentukan karakter mahasiswa. Langkah lain yang ditempuh dalam segi pendidikan ialah membekali mahasiswa berupa kemampuan-kemampuan dan keterampilan mengajar yang benar menurut kesesuaian aturan- aturan metode pembelajaran.

Mahasiswa prodi Geografi yang telah melaksanakan Program magang III, diharapkan benar-benar siap mengajar di suatu sekolah. Unsur-unsur yang menbuat mahasiswa siap melaksanakan magang III antara lain: bimbingan konseling kepada mahasiswa, Mata Kuliah Dasar Kependidikan yang telah ditempuh dengan tuntas oleh mahasiswa, mengikuti mata kuliah Micro Teaching, mempraktikkan mengajar micro hingga benar-benar menguasai ketrampilan mengajar yang dibutuhkan, mengikuti ujian Micro Teaching hingga dinyatakan lulus, kesiapan psikis, dan kesehatan mahasiswa sebelum diterjunkan ke sekolah mitra untuk melaksanakan magang III. Departemen Pendidikan dan Kebudayaan (dalam Andrasmoro, 2016) menyatakan bahwa "PPL atau magang III merupakan salah satu kegiatan kurikuler yang kulminasi dari seluruh program pendidikan yang telah dihayati dan dialami oleh mahasiswa di lembaga pendidikan tenaga kependidikan".

Magang III dapat diartikan sebagai program yang merupakan tempat untuk menerapkan berbagai pengetahuan, sikap dan keterampilan dalam rangka pembentukan guru yang profesional. Selain itu juga program magang III juga bertujuan untuk memenuhi persyaratan dalam pembentukan tenaga pendidikan yang mampu mencapai tingkat profesional hingga dapat dijadikan sebagai profesi kependidikan. Hal ini 
ditujukan untuk pembentukan profesionaltias guru maupun bagi tenaga kependidikan yang lain selain guru. Melalui program tersebut diharapkan mahasiswa praktikan dapat mempraktikkan di tempat yang sesungguhnya yaitu di sekolah lanjutan atas maupun di sekolah lanjutan pertama dengan situasi dan kondisi yang berbeda-beda.

Suparno (1994) mengatakan bahwa Pelaksanaan Program Pengalaman Lapangan (Praktik Kependidikan) ditujukan untuk pembentukan guru/tenaga kependidikan yang profesional melalui kegiatan pelatihan di sekolah, agar mahasiswa calon guru: "(1) menguasai berbagai keterampilan dasar mengajar, dan (2) menerapkan berbagai kemampuan profesional keguruan, (3) menarik kesimpulan nilai edukatif dari penghayatan dan pengalaman secara pelatihan melalui refleksi, dan menuangkan hasil refleksi itu ke dalam bentuk laporan". Pelaksanaan PPL atau program magang III ini telah melalui persiapan-persiapan teori maupun praktik agar mahasiswa praktikan tidak merasa kaku di hadapan siswa, karena sebelum terjun ke lapangan tempat praktik terlebih dahulu telah melakukan micro teaching yaitu merupakan suatu praktik keguruan dengan ukuran kecil yang terdapat di matakuliahh pembelajaran mikro. Melalui praktik yang sederhana ini, diharapkan mahasiswa praktikan dapat mempraktikkan di tempat yang sesungguhnya yaitu di sekolah lanjutan atas maupun di sekolah lanjutan pertama dengan situasi dan kondisi yang berbeda-beda.

Mahasiswa prodi geografi yang telah melaksanakan Program Pengalaman Lapangan (PPL) atau program magang III ini diharapkan benar-benar siap mengajar di suatu sekolah. Unsur-unsur yang menbuat mahasiswa siap melaksanakan magang antara lain: 1) bimbingan konseling kepada mahasiswa, 2) Mata Kuliah Dasar Kependidikan yang telah ditempuh dengan tuntas oleh mahasiswa, 3) mengikuti mata kuliah pembelajaran mikro, 4) mempraktikkan mengajar mikro hingga benar-benar menguasai keterampilan mengajar yang dibutuhkan, 5) mengikuti ujian micro teaching hingga dinyatakan lulus, 6) kesiapan psikis, dan 7) kesehatan mahasiswa sebelum diterjunkan ke sekolah mitra untuk melaksanakan magang III. "Ada pengaruh yang sangat signifikan antara matakuliahh pembelajaran mikro terhadap kesiapan mengajar mahasiswa magang Progran Studi Pendidikan Ekonomi STKIP PGRI Tulungagung" (Rindrayani, 2016).

Hal ini dapat diartikan bahwa apabila nilai pembelajaran mikro baik maka akan diikuti kemampuan mengajar mahasiswa baik. Artinya bahwa mahasiswa dalam pelaksanaan pembelajaran mikro mahasiswa sudah dapat menerapkan delapan ketrampilan dasar mengajar meliputi ketrampilan membuka pelajaran, menutup pelajran, menjelaskan, pengelolaan kelas, keterampilan bertanya, memberikan penguatan, mengajar kelompok kecil, dan membimbing diskusi dengan baik. Delapan Keterampilan dasar yang dapat dilakukan dengan baik ini berakibat pada kemampuan mengajar pada kegiatan magang dapat dilaksanakan dengan baik, yaitu dalam membuat RPP, melaksanakan pembelajaran, dan refleksi. 


\section{METODE PENELITIAN}

Rancangan penelitian ini menggunakan rancangan kuantitatif dengan pendekatan korelasional, dimana nanti akan dicari pengaruh dan seberapa signifikan tingkat dari pengaruhnya yang terjadi. Dalam penelitian ini terdapat variabel bebas, yaitu pembelajaran mikro $(\mathrm{X})$ dan variabel terikat yaitu program magang III (Y). Populasi dalam penelitian ini adalah mahasiswa Pogram Studi Pendidikan Geografi semester VIII yang telah menempuh matakuliah pembelajaran mikro dan magang III sejumlah 156 mahasiswa. Teknik sampling dalam penelitian ini adalah Proportional random sampling, bahwa sampel diambil 30\% dari 156 siswa yaitu 44 mahasiswa.

Instrumen penelitian yang digunakan yakni penilaian kemampuan merencanakan pembelajaran dan kemampuan melaksanakan pembelajaran serta dokumen mengenai hasil belajar pembelajaran mikro dan hasil nilai magang III. Pengujian hipotesis dalam penelitian ini menggunakan t-test. Adapun tingkat signifikasi yang digunakan yaitu $5 \%$. Penghitungan analisis data menggunakan program SPSS 16.0 for Windows.

\section{HASIL DAN PEMBAHASAN}

Pengelompokan skor kesiapan magang III menggunakan acuan skor akhir 91100; sangat siap, 84-90,9; siap, 77-83,9; cukup siap, 71-76,9; kurang siap, dan 66-70,9; tidak siap. Adapun rata-rata nilai pembelajaran mikro dan magang III dapat dilihat pada tabel berikut ini.
Tabel 1. Rata-rata Nilai

Pembelajaran Mikro dan Magang III

\begin{tabular}{cccc}
\hline No & Variabel & $\begin{array}{c}\text { Rata- } \\
\text { rata } \\
\text { Skor }\end{array}$ & Kategori \\
\hline 1 & $\begin{array}{c}\text { Pembelajaran } \\
\text { Mikro }\end{array}$ & 90 & Siap \\
2 & Magang III & 88 & Siap \\
\hline
\end{tabular}

Tabel 1. menunjukkan rata-rata nilai pembelajaran micro termasuk kategori Siap. Sedangkan rata-rata nilai magang III termasuk kategori siap. Namun nilai pembelajaran micro memiliki rata-rata lebih tinggi jika dibandingkan dengan nilai magang III yaitu untuk nilai micro sebesar 90 dan nilai magang III sebesar 88. Hasil keterampilan mengajar angkatan 2013 dijelaskan pada grafik 1 berikut.

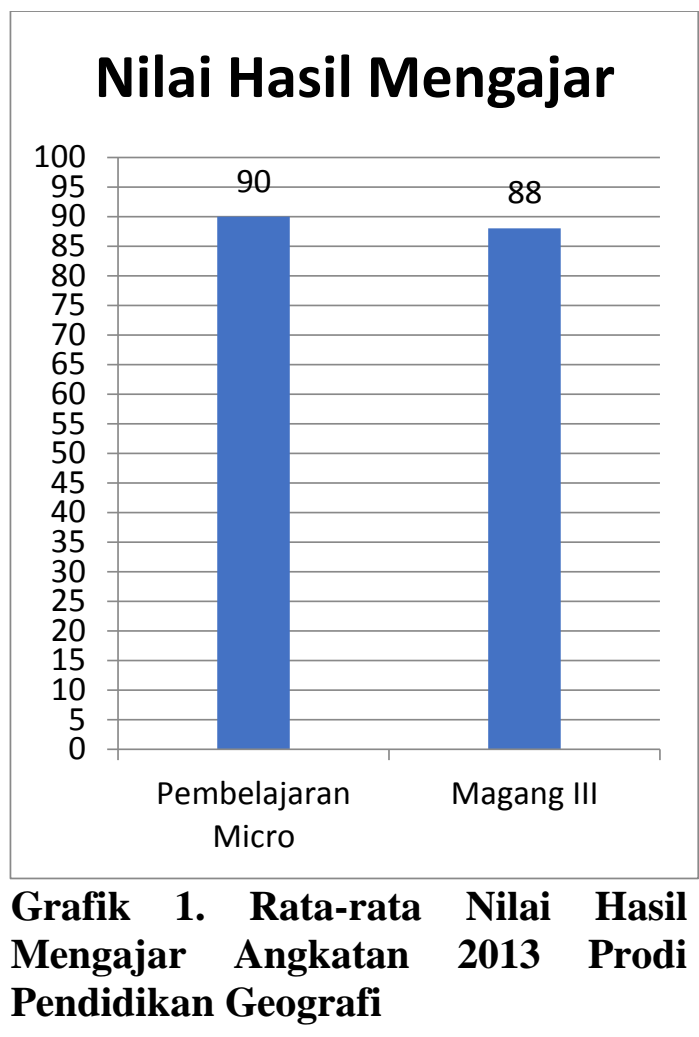




\section{Pengaruh Pembelajaran Micro terhadap Kesiapan Program Magang III}

Profesi guru sangat berkaitan dengan lima kompetensi yang harus dipersiapkan antara lain: kompotensi pedagogis, profesional, sosial, kepribadian, dan menejerial. Kompetensi tersebut harus dipersiapkan pada prodi pendidikan dengan sistem kurikulum yang sistematis, sehingga kesiapan mahasiswa sebagai calon guru lebih maksimal. Berkaitan dengan kompetensi pedagogis, seorang guru harus bisa menguasai materi dan mengajarkan kepada siswanya. Oleh karena itu, dalam kurikulum di Prodi Pendidikan ada matakuliah pembelajaran micro yang bertujuan untuk melatih keterampilan mahasiswa dalam praktik mengajar di sekolah. Selanjutnya Rindrayani (2016) menjelaskan bahwasanya "perlu peningkatan kualitas pembelajaran micro kepada mahasiswa sehingga mampu menerapkan keterampilan dasar mengajar sebagai bekal pelaksanaan magang III".

Hasil analalisis data membuktikan bahwa ada pengaruh yang signifikan antara pembelajaran micro terhadap kemampuan mengajar mahasiswa pada magang III Progran Studi Pendidikan Geografi. Hal ini dapat diartikan bahwa apabila hasil nilai micro teaching baik maka akan diikuti kemampuan mengajar mahasiswa baik. Artinya bahwa mahasiswa dalam pelaksanaan pembelajaran micro teaching sudah dapat menerapkan 13 keterampilan dasar mengajar meliputi 1) membuka pelajaran, 2) menggunakan metode mengajar, 3) menggunakan media pembelajaran, 4) menjelaskan, 5) mengelola pertanyaan, 6) penguasaan bahan ajar, 7) kemampuan mengelola kelas, dan 8) pengelolaan waktu, 9) gerak guru dalam mengajar, 10) suara guru dalam mengajar, 11) arah pandangan mata, 12) pemberian penguatan, dan 13) menutup pelajaran (LP3L, 2016). Ketigabelas keterampilan dasar yang dapat dilakukan dengan baik ini berakibat pada kemampuan mengajar mahasiswa pada kegiatan magang III.

Banyak faktor yang mempengaruhi terbangunnya suatu kinerja professional. Termasuk, kinerja seorang guru yang di dalamnya berkaitan dengan faktor-faktor yang mempengaruhi kemampuan mengajarnya, baik secara internal maupun eksternal. Kinerja sangat berkaitan dengan hasil kerja. Kondisi tersebut sesuai dengan pendapat Hasibuan (2003) menyatakan bahwa "kinerja atau prestasi kerja adalah suatu hasil kerja yang dicapai seseorang dalam melaksanakan tugas yang dibebankan kepadanya yang didasarkan atas kecakapan, pengalaman, dan kesungguhan serta waktu". Faktor internal yang mempengaruhi misalnya sistem kepercayaan yang menjadi pandangan hidup (way of life) seorang guru, hal tersebut memiliki pengaruh yang besar dalam meningkatkan kemampuan serta profesionalitas seorang guru. Menyangkut faktor eksternal kemampuan kinerja guru, Dewi (2015) menjelaskan beberapa hal, di antaranya yaitu:

1) volume upah kerja yang dapat memenuhi kebutuhan seseorang, 2) suasana kerja yang menggairahkan atau iklim yang ditunjang dengan komunikasi demokrasi yang serasi dan manusiawi antara pimpinan dan bawahan, 3) penanaman sikap dan pengertian dikalangan pekerja, 4) sikap jujur dan dapat dipercaya dari kalangan pimpinan tewujud dalam kenyataan, (5) penghargaan terhadap need for achievement (hasrat dan kebutuhan untuk maju) atau penghargaan bagi yang berprestasi, 
dan (6) sarana yang menunjang bagi kesejahteraan mental dan fisik, seperti tempat olahraga, masjid, rekreasi, hiburan dan lain-lain.

Kondisi tersebut menunjukkan bahwa nilai micro teaching bukan merupakan satusatunya faktor yang dapat memengaruhi kemampuan mengajar magang III. Salah satu yang menjadi keterbaasan dalam penelitian ini adalah tidak semuanya mahasiswa yang memiliki nilai micro teaching baik maka kemampuan mengajarnya juga baik, begitupun sebaliknya. Hal ini bisa dibuktikan secara ilmiah, namun ada faktor lain yang mempengaruhi kemampuan mengajar magang III baik secara internal maupun eksternal terdiri dari kepribadian, keluarga, dan lingkungan. Dalam penelitian ini pula, seringkali peneliti menemui kesulitan dalam memberikan pemahaman kepada guru pamong atau observer dalam kaitanya dengan apa yang akan diteliti, hal tersebut seringkali disebabkan oleh intensitas waktu bertemu dengan guru pamong masingmasing mahasiswa praktikan.

\section{KESIMPULAN DAN SARAN}

\section{Kesimpulan}

Berdasarkan hasil penelitian dan pembahasan dapat ditarik kesimpulan yakni ada pengaruh yang signifikan antara pembelajaran micro terhadap kesiapan program magang III.

\section{Saran}

Berdasarkan kesimpulan dapat disarankan hal-hal sebagai berikut:

1. Bagi dosen, dalam mengampu matakulia pembelajaran micro disarankan untuk lebih detail memperhatikan kemampuan kesesuaian antara merencanakan pembelajaran (RPP) dan kemampuan melaksanakan pembelajaran (praktik ngajar).
2. Bagi peneliti selanjutnya, disarankan untuk menguji pengaruh pembelajaran micro terhadap variabel lain.

\section{DAFTAR PUSTAKA}

Andrasmoro, Dony \& Nurekawati, Endah Evy. 2016. Analisis Kesiapan Mahasiswa dalam Melaksanakan Program Pengalaman Lapangan di Prodi Pendidikan Geografi Tahun 2015. Jurnal Pendidikan Sosial, 3(1): 29-40.

Dewi, Tiara Anggia. 2015. Pengaruh Profesionalisme Guru dan Motivasi Kerja terhadap Kinerja Guru Ekonomi SMA se-Kota Malang. Jurnal Pendidikan Ekonomi UM Metro. 3(1): 24-35.

Cahyati, Arlian Ayu. 2014. Pengaruh Mata Kuliah Micro Teaching dan Praktik Pengalaman Lapangan (PPL) Terhadap Tingkat Kematangan Calon Guru Pada Mahasiswa Pendidikan Ekonomi Akuntansi Angkatan 2010 Universitas Muhammadiyah Surakarta. (Online), (http://eprints.ums.ac.id/29830/13/ 9._naskah_publikasi.pdf, diakses 2 Februari 2017).

Hasibuan, Malayu SP. 2003. Organisasi Dan Motivasi. Jakarta: PT Bumi Aksara.

LP3L. 2016. Pedoman Magang Program Studi Kependidikan. Malang: Universitas Kanjuruhan Malang.

Mukondar \& Susanto, Arif. 2015. Pengaruh Micro Teaching dan Praktik Industri terhadap 
Kesiapan Praktik Pengalaman

Lapangan (PPL) mahasiswa

Program Studi Pendidikan Teknik

Otomotif Universitas

Muhammadiyah Purworejo.

Jurnal Pendidikan Teknik

Otomotif_Universitas

Muhammadiyah Purworejo, 5(2): 156-159.

Rindrayani, Sulastri Rini. 2016.

Pengaruh Micro Teaching dan Bimbingan Guru Pamong Terhadap Kemampuan Mengajar Mahasiswa Magang Program Studi Pendidikan Ekonomi STKIP PGRI Tulungagung. (Online), (5file:///C:/Users/S1001/Downloa ds/650-1165-1-SM.pdf, diakses 3 Februari 2017).

Slameto. 2010. Belajar dan Faktorfaktor yang Mempengaruhinya. Jakarta: PT Rineka Cipta.

Suparno, A.S. \& Wardani, I.G.K. 1994. Program Pengalaman Lapangan. Jakarta: Direktorat Jenderal Pendidikan Tinggi Departemen Pendidikan dan Kebudayaan. 